\title{
Amphidinol 22, a New Cytotoxic and Antifungal Amphidinol from the Dinoflagellate Amphidinium carterae
}

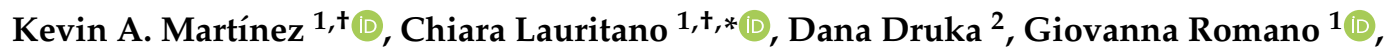 \\ Teresa Grohmann ${ }^{3}$, Marcel Jaspars ${ }^{2}$, Jesús Martín ${ }^{4}$, Caridad Díaz ${ }^{4}$, Bastien Cautain ${ }^{4}$, \\ Mercedes de la Cruz ${ }^{4}\left(\mathbb{D}\right.$, Adrianna Ianora ${ }^{1, \ddagger}$ and Fernando Reyes ${ }^{4, \ddagger}$ (D) \\ 1 Department of Marine Biotechnology, Stazione Zoologica Anton Dohrn, 80121 Naples, Italy \\ 2 Marine Biodiscovery Centre, Department of Chemistry, University of Aberdeen, Aberdeen AB24 3UE, \\ Scotland, UK \\ 3 The Rowett Institute, University of Aberdeen, Aberdeen AB25 2ZD, Scotland, UK \\ 4 Fundación MEDINA, Centro de Excelencia en Investigación de Medicamentos Innovadores en Andalucía, \\ Avda. del Conocimiento 34, 18016 Granada, Spain \\ * Correspondence: chiara.lauritano@szn.it; Tel.: +39-081-5833221 \\ + The two authors contributed equally to this work. \\ $\ddagger \quad$ The two authors also contributed equally to this work.
}

Received: 31 May 2019; Accepted: 24 June 2019; Published: 27 June 2019

\begin{abstract}
Due to the unique biodiversity and the physical-chemical properties of their environment, marine microorganisms have evolved defense and signaling compounds that often have no equivalent in terrestrial habitats. The aim of this study was to screen extracts of the dinoflagellate Amphidinium carterae for possible bioactivities (i.e., anticancer, anti-inflammatory, anti-diabetes, antibacterial and antifungal properties) and identify bioactive compounds. Anticancer activity was evaluated on human lung adenocarcinoma (A549), human skin melanoma (A2058), human hepatocellular carcinoma (HepG2), human breast adenocarcinoma (MCF7) and human pancreas carcinoma (MiaPaca-2) cell lines. Antimicrobial activities were evaluated against Gram-positive bacteria (Staphylococcus aureus MRSA and MSSA), Gram-negative bacteria (i.e., Escherichia coli and Klebsiella pneumoniae), Mycobacterium tuberculosis and the fungus Aspergillus fumigatus. The results indicated moderate biological activities against all the cancer cells lines and microorganisms tested. Bioassay-guided fractionation assisted by HRMS analysis allowed the detection of one new and two known amphidinols that are potentially responsible for the antifungal and cytotoxic activities observed. Further isolation, purification and structural elucidation led to a new amphidinol, named amphidinol 22. The planar structure of the new compound was determined by analysis of its HRMS and 1D and 2D NMR spectra. Its biological activity was evaluated, and it displayed both anticancer and antifungal activities.
\end{abstract}

Keywords: marine microalgae; dinoflagellates; marine natural products (MNPs); bioactive compounds; blue biotechnology; amphidinol; antifungal; anticancer

\section{Introduction}

Many microalgae, including dinoflagellates, are known to produce compounds with a wide range of biological and biochemical properties [1]. The biodiversity of marine phytoplankton species leads to a great metabolic variety that renders them a huge reservoir of new bioactive compounds with multiple possible pharmaceutical applications [2] (e.g. cytotoxic, anticancer, antibiotic, antifungal, immunosuppressant and neurotoxic activities [3-10]). Bioactive compounds of microalgal origin can be sourced directly from primary metabolism (e.g. proteins, fatty acids, vitamins and pigments) or 
can be synthesized from secondary metabolism. Microalgae are in fact excellent sources/producers of carotenoids, polysaccharides, vitamins, lipids as well as potent neurotoxins [11]. In the last decade, an increasing number of studies have focused their attention on microalgal compounds for the treatment of various human pathologies or for nutraceutical applications [12,13].

Amphidinium carterae is an athecate dinoflagellate, found in both temperate and tropical waters [14]. Pagliara and Caroppo [15] showed that when embryos of the sea urchin Paracentrotus lividus were reared on a Mediterranean strain of $A$. carterae, there was a $60 \%$ embryo growth inhibition after exposure to $3.75 \mathrm{mg} / \mathrm{mL}$ of $A$. carterae cell lysate and $100 \%$ inhibition with $7.5 \mathrm{mg} / \mathrm{mL}$. They also observed an $\mathrm{LC}_{50}$ value of $3.67 \mathrm{mg} / \mathrm{mL}$ after $24 \mathrm{~h}$ exposure of the brine shrimp Artemia salina to the A. carterae cell lysate. Shah and co-workers found antioxidant activity at $1 \mathrm{mg} / \mathrm{mL}$ of methanolic extract of $A$. carterae, $80 \%$ nitric oxide (NO) production inhibition at $50 \mu \mathrm{g} / \mathrm{mL}$ in LPS-induced RAW 264.7 macrophages and $20 \%$ reduction in human promyelocytic leukemia (HL-60) cell viability at $50 \mu \mathrm{g} / \mathrm{mL}$ [16]. In addition, it was also reported that an extract from another Amphidinium strain had antifungal properties and was able to inhibit the growth of the fungus Candida albicans at $32 \mu \mathrm{g} / \mathrm{mL}$ [17].

Until now, various Amphidinium strains have displayed different biological activities and chemical diversity [17-23]. Various compounds have been isolated from these strains, including the amphidinols (AM), amphirionins, karatungiols and more than 45 cytotoxic macrolides, known as amphidinolides. Most of the mentioned compounds present polyketidic skeletons, but it seems that not all of the Amphidinium strains possess the enzymatic machinery responsible for polyketide synthesis $[24,25]$.

The aim of this study was to screen A. carterae (clone FE102) for various bioactivities useful for the treatment of human pathologies (i.e., anticancer, antibacterial and antifungal properties) and isolate potential active metabolites. In the transcriptome of the same clone, we recently found the sequence coding $\beta$-ketosynthase [26], an enzyme involved in polyketide synthesis, suggesting the production of potential active secondary metabolites. Raw extracts from $A$. carterae were tested against various bioactivity platforms including both human and bacterial cells. We evaluated the anti-bacterial activity on Gram-positive bacteria (Staphylococcus aureus MRSA, Staphylococcus aureus MSSA), Gram-negative bacteria (Escherichia coli and Klebsiella pneumoniae) and Mycobacterium tuberculosis. The antifungal activity was assessed on Aspergillus fumigatus. Anticancer activity was also evaluated against a panel of five different cancer cell lines (i.e., human lung carcinoma A549 ATCC ${ }^{\circledR}$ CCL-185 ${ }^{\mathrm{TM}}$, human skin melanoma A2058 ATCC ${ }^{\circledR}$ CRL-11147 ${ }^{\mathrm{TM}}$, hepatocyte carcinoma HepG2 ATCC ${ }^{\circledR}$ HB-8065 ${ }^{\mathrm{TM}}$, breast adenocarcinoma MCF7 ATCC ${ }^{\circledR}$ HTB-22 ${ }^{\mathrm{TM}}$ and pancreas carcinoma MiaPaca-2 ATCC ${ }^{\circledR}$ CRL-1420 ${ }^{\mathrm{TM}}$ ). Bioassay-guided fractionation followed by HRMS analyses yielded the new amphidinol 22. The amphidinols are a family of bioactive polyketides with a well-known antifungal and hemolytic activity, as reported in the literature $[17,21,27,28]$. Espiritu et al. have also reported that amphidinol 2 (AM2) displayed anticancer properties [29]. Amphidinol 22 biological activity was evaluated and it showed both anticancer and antifungal activity.

\section{Experimental Section}

\subsection{Cell Culturing and Harvesting}

A. carterae (CCMP1314) was grown in Keller medium [30] in ten-liter polycarbonate carboys (each experiment was performed in triplicate) constantly bubbled with air filtered through $0.2 \mu \mathrm{m}$ membrane filters. Cultures were kept in a climate chamber at $20^{\circ} \mathrm{C}$ on a $12: 12 \mathrm{~h}$ light:dark cycle at $110 \mu \mathrm{mol}$ photons $\mathrm{m}^{-2} \mathrm{~s}^{-1}$. Initial cell concentrations were about 5000 cells $/ \mathrm{mL}$ for each experiment and culture growth rate was monitored, using the equation for net growth estimates [31]. For the isolation of the pure compound, fifteen replicates of ten-liter cultures have been used. The biomass was harvested during the stationary phase (in the same day and at the same time of the day for each replicate to avoid possible interference by intrinsic circadian rhythms) by centrifugation for $10 \mathrm{~min}$ at $4{ }^{\circ} \mathrm{C}$ at $2300 \mathrm{rpm}$ (Beckman Coulter Allegra ${ }^{\circledR}$ 6R centrifuge). Microalgal biomasses were kept at $-80^{\circ} \mathrm{C}$ until chemical extraction. 


\subsection{Chemical Extraction}

Methanol was filled into the tubes to reach two times the volume of the biomass. The tubes were vortexed to ensure that methanol completely soaked the material that was then placed into a Kuhner ISF4-X Climo-Shaker for $3 \mathrm{~h}$ at $20^{\circ} \mathrm{C}$. The tubes were then centrifuged at $3000 \mathrm{rpm}$ for $20 \mathrm{~min}$, and the supernatant was transferred to $40 \mathrm{~mL}$ EPA vials (dispolab) and evaporated under nitrogen stream. Aliquots from the dried extracts were lyophilized and dissolved in DMSO for testing and HPLC-UV-MS analysis. The extract yield of the A. carterae broth was $50 \mathrm{mg} / \mathrm{L}$ approximately.

\subsection{Anticancer Assays}

Colorimetric MTT ((3-(4,5-Dimethylthiazol-2-yl)-2,5-diphenyltetrazolium bromide)) assays were carried out to assess the cell viability of the samples against a panel of five different cancer cell lines (i.e., human lung carcinoma $\mathrm{A} 549$ ATCC ${ }^{\circledR}$ CCL-185 ${ }^{\mathrm{TM}}$, human skin melanoma A2058 ATCC ${ }^{\circledR}$ CRL-11147 ${ }^{\mathrm{TM}}$, hepatocyte carcinoma HepG2 ATCC ${ }^{\circledR}$ HB-8065 ${ }^{\mathrm{TM}}$, breast adenocarcinoma MCF7 ATCC ${ }^{\circledR}$ HTB-22 ${ }^{\mathrm{TM}}$ and pancreas carcinoma MiaPaca-2 ATCC ${ }^{\circledR}$ CRL-1420 ${ }^{\mathrm{TM}}$ ). All cells were obtained from the American Type Culture Collection (ATCC, Manassas, VA, USA). A549 cells were grown in Ham's F12K medium with $2 \mathrm{mM}$ Glutamine, 10\% Fetal Bovine Serum (FBS), $100 \mathrm{U} / \mathrm{mL}$ penicillin and $100 \mu \mathrm{g} / \mathrm{mL}$ streptomycin. A2058 and HepG2 were grown in ATCC formulated Eagle's M essential medium (MEM) with $10 \%$ FBS, $2 \mathrm{mM}$ L-glutamine, $1 \mathrm{mM}$ sodium pyruvate and $100 \mu \mathrm{M}$ MEM non-essential amino acids. MCF-7 cells were grown in the previous medium supplemented with $0.01 \mathrm{mg} / \mathrm{mL}$ of bovine insulin. MiaPaca-2 cells were grown in Dulbecco's Modified Eagle's Medium (DMEM) with 10\% FBS, 100U/mL penicillin and $100 \mu \mathrm{g} / \mathrm{mL}$ streptomycin. The bioassays were performed as reported by Audoin et al. [32]. The anticancer activity was assessed after $72 \mathrm{~h}$ of treatment with amphidinol 22 at the concentrations $0.098,0.195,0.391,0.781,1.563,3.125,6.250,12.5,25$ and $50 \mu \mathrm{M}$. The raw algal extract was tested at $175 \mu \mathrm{g} / \mathrm{mL}$.

\subsection{Antifungal Assays}

The fungi C. albicans ATCC64124 and A. fumigatus ATCC46645 were used as test organisms to assess antifungal activity as reported in Audoin et al. [32]. For C. albicans the growth inhibition was calculated measuring the OD at $612 \mathrm{~nm}$, while for A. fumigatus it was based on the fluorescence development derived from the conversion of resazurin to resorufin (excitation $570 \mathrm{~nm}$ and emission $600 \mathrm{~nm}$ ). The antifungal activity was assessed after 20-30 h of treatment with amphidinol 22 at the concentrations $0.075,0.15,0.3,0.6,1.25,2.5,5,10,20$ and $40 \mu \mathrm{M}$. The raw algal extract was tested at $560 \mu \mathrm{g} / \mathrm{mL}$.

\subsection{Antibacterial Assays}

A panel of five different bacteria (i.e., the Gram-negative bacteria E. coli ATCC25922 and K. pneumoniae ATCC700603, and Gram-positive bacteria S. aureus MRSA MB5393 and MSSA ATCC29213) were used as test organisms for the antibacterial MIC (minimum inhibitory concentration) assays that were performed as reported in Audoin et al. [32]. The antibacterial activity was assessed after $20 \mathrm{~h}$ of treatment with amphidinol 22 at the concentrations $0.075,0.15,0.3,0.6,1.25,2.5,5,10,20$ and $40 \mu \mathrm{M}$. The raw algal extract was tested at $560 \mu \mathrm{g} / \mathrm{mL}$. The antitubercular activity of the samples against $M$. tuberculosis H37Ra was determined using the REMA method [33].

\subsection{General Chemical Analysis Procedures}

Samples were analyzed by HPLC-UV-HRMS on an Agilent 1200 RR coupled to a Bruker maXis time-of-flight spectrometer with electrospray ionization, as reported by Martin et al. [34]. Mass spectra were collected as full scans from $50 \mathrm{~m} / \mathrm{z}$ to $2000 \mathrm{~m} / \mathrm{z}$. Data were analyzed using the platform available at Fundación MEDINA [35] and compared with the data available in the Dictionary of Marine Natural Products database [36] and PubChem [37]. NMR spectra were acquired using a Bruker Avance $500 \mathrm{MHz}$ 
spectrometer with a pulsed field gradient and referenced to signal solvent signals (CD3OD, at $\delta \mathrm{H}$ 3.31 and $\delta C 49.0 \mathrm{ppm})$. The solvents used were HPLC grade.

\subsection{Fractionation}

The crude microalgal extract $(5.67 \mathrm{~g})$ was fractionated through reverse phase C18 $(110 \mathrm{~mm} \times$ $40 \mathrm{~mm}$ column) flash chromatography to separate the extract into 80 different fractions using a gradient of $\mathrm{H} 2 \mathrm{O}$ (Solvent A) and $\mathrm{CH} 3 \mathrm{CN}$ (Solvent B). The method went from 5\% B to $100 \%$ B in $40 \mathrm{~min}$ and it was maintained at $100 \% \mathrm{~B}$ for another $40 \mathrm{~min}$. The flow rate was $18 \mathrm{~mL} / \mathrm{min}$ and the wavelengths selected were 210 and $260 \mathrm{~nm}$, according to the data from HPLC-UV-MS. The fractions 19 and 20 (17.73 mg, eluted at $48 \%$ B) were pooled and further fractionated by semi-preparative reversed-phase HPLC-DAD (column Zorbax SB-C8, $4.6 \mathrm{~mm} \times 150 \mathrm{~mm}, 5 \mu \mathrm{m}$ particle size) with a flow of $3.6 \mathrm{~mL} / \mathrm{min}$ and a $\mathrm{H} 2 \mathrm{O}: \mathrm{CH} 3 \mathrm{CN}$ gradient (75:25 to $68: 32$ in $36 \mathrm{~min}$ ) as eluent. Amphidinol 18 (identified by HPLC-UV-MS) and amphidinol 22 were isolated. Amphidinol 22 was obtained as a pale yellow solid $(1.4 \mathrm{mg})$ and it was tested for anticancer, antifungal and antibacterial activity using 10-point serial dilutions (1:1 dilutions), with initial concentrations of $50 \mu \mathrm{M}$ in the case of the anticancer assays, and $40 \mu \mathrm{M}$ in the case of the antibacterial and antifungal assays.

\subsection{Amphidinol 22}

Pale yellow, amorphous solid; UV (MeOH) $\lambda_{\max }$ 282, 270 and $260 \mathrm{~nm}$; NMR data available (CD3OD), see Table 1; HRESIMS m/z 1662.9705 [M + NH4] ${ }^{+}$(calcd for C84H144O31 ${ }^{+}, 1662.9717, \Delta$ $-0.7 \mathrm{ppm}$ ); $1645.9515[\mathrm{M}+\mathrm{H}]^{+}$(calcd for $\left.\mathrm{C} 84 \mathrm{H} 141 \mathrm{O} 31^{+}, 1645.9451, \Delta 3.9 \mathrm{ppm}\right) ; 1627.9371[\mathrm{M}-\mathrm{H} 2 \mathrm{O}+$ $\mathrm{H}^{+}$(calcd for C84H139O30 $\left.{ }^{+}, 1627.9346, \Delta 1.5 \mathrm{ppm}\right) .1 \mathrm{H} \mathrm{NMR}(500 \mathrm{MHz}),{ }^{13} \mathrm{C} \mathrm{NMR}(125 \mathrm{MHz}), \mathrm{HSQC}$, COSY, HMBC, NOESY, LC-UV trace and UV and HRESIMS spectra of amphidinol 22, expansions of the HRESIMS spectrum, and the tabulated 2D NMR data are available in the supplementary information (Figures S1-S8 and Table S9, respectively).

\subsection{Statistical Analysis}

Statistical differences between treated and control cells for all the assays performed in this study were determined by Student's $t$-test using GraphPad Prim statistic software, V4.00 (GraphPad Software, San Diego, California, USA). Data were considered significant when at least $p$ was $<0.05$ ( ${ }^{*}$ for $p<0.05$, ** for $p<0.01$, and ${ }^{* * *}$ for $p<0.001$ ).

\section{Results and Discussion}

\subsection{Preliminary Bioactivity Screening of Raw Extract and HPLC-UV-MS Analysis}

The isolation of new bioactive metabolites was performed following a bioassay-guided fractionation approach supported by HRMS analysis. After extraction of the A. carterae biomass, the crude extract was tested against a panel of different cancer cell lines, bacteria and fungi. For each assay, three biological replicates were tested and two technical replicates per sample were performed. Table 2 summarizes the outputs from the bioassays. 
Table 1. NMR data of amphidinol $22(500 \mathrm{MHz})$ in CD3OD.

\begin{tabular}{|c|c|c|c|c|c|}
\hline Carbon & $\delta^{13} \mathrm{C}$ & $\delta^{1} \mathbf{H}$, mult, $J(\mathrm{~Hz})$ & Carbon & $\delta^{13} \mathrm{C}$ & $\delta^{1} \mathbf{H}$, mult, $J(\mathrm{~Hz})$ \\
\hline 1 & 14.09 & $0.91, \mathrm{t}, 7.4$ & 43 & 41.90 & $1.97, \mathrm{~m} ; 1.51, \mathrm{~m}$ \\
\hline 2 & 23.58 & $1.42, \mathrm{~m}, 2 \mathrm{H}$ & 44 & 71.79 & $3.85, \mathrm{~m}$ \\
\hline 3 & 35.83 & $2.06, \mathrm{~m}$ & 45 & 36.68 & $1.67, \mathrm{~m} ; 1.58, \mathrm{~m}$ \\
\hline 4 & 136.10 & $5.69, \mathrm{~m}$ & 46 & 36.68 & $2.20, \mathrm{~m} ; 2.11, \mathrm{~m}$ \\
\hline 5 & 131.23 & $6.05, \mathrm{dd}, 15.2,10.5$ & 47 & 139.30 & Null \\
\hline 6 & 132.41 & $6.22, \mathrm{dd}, 15.7,10.4$ & 48 & 126.24 & 5.48, br d, 8.7 \\
\hline 7 & 134.08 & $5.61, \mathrm{dd}, 15.2,8.6$ & 49 & 67.97 & $4.56, \mathrm{dd}, 8.9,1.7$ \\
\hline 8 & 71.39 & 4.26 , ddd, $6.6,6.6,6.6$ & 50 & 72.50 & $3.68, \mathrm{dd}, 9.5,1.9$ \\
\hline 9 & 40.90 & $1.75, \mathrm{~m}, 2 \mathrm{H}$ & 51 & 79.21 & $3.95, \mathrm{~m}$ \\
\hline 11 & 62.32 & $2.72, \mathrm{dd}, 5.2,2.1$ & 53 & 67.48 & $3.97, \mathrm{~m}$ \\
\hline 12 & 71.91 & $3.41, \mathrm{~m}$ & 54 & 30.41 & $1.76, \mathrm{~m}$ \\
\hline 13 & 35.35 & $1.62, \mathrm{~m} ; 1.48, \mathrm{~m}$ & 55 & 75.71 & $3.48, \mathrm{~m}$ \\
\hline 14 & 22.89 & $1.77, \mathrm{~m} ; 1.44, \mathrm{~m}$ & 56 & 74.63 & $3.60, \mathrm{~m}$ \\
\hline 15 & 32.90 & $1.89, \mathrm{~m} ; 1.44, \mathrm{~m}$ & 57 & 32.44 & $1.96, \mathrm{~m} ; 1.55, \mathrm{~m}$ \\
\hline 16 & 81.54 & $3.07, \mathrm{~m}$ & 58 & 27.89 & $2.41, \mathrm{~m} ; 2.09, \mathrm{~m}$ \\
\hline 17 & 73.10 & $3.38, \mathrm{~m}$ & 59 & 151.35 & Null \\
\hline 18 & 76.77 & $3.39, \mathrm{~m}$ & 60 & 76.77 & $4.18, d, 8.9$ \\
\hline 19 & 69.89 & $4.08, \mathrm{~m}$ & 61 & 75.23 & $3.35, \mathrm{~m}$ \\
\hline 20 & 82.36 & 3.14, br d, 8.9 & 62 & 70.41 & $4.04, \mathrm{~m}$ \\
\hline 21 & 68.63 & $3.87, \mathrm{~m}$ & 63 & 31.55 & $2.08, \mathrm{~m} ; 1.55, \mathrm{~m}$ \\
\hline 22 & 35.14 & $2.05, \mathrm{~m} ; 1.74, \mathrm{~m}$ & 64 & 67.36 & $4.05, \mathrm{~m}$ \\
\hline 23 & 77.92 & $4.22, \mathrm{~m}$ & 65 & 68.73 & $4.04, \mathrm{~m}$ \\
\hline 24 & 71.63 & $3.64, \mathrm{~m}$ & 66 & 80.58 & 3.74, br d, 9.9 \\
\hline 25 & 67.32 & $3.92, \mathrm{~m}$ & 67 & 72.01 & 3.97, m \\
\hline 26 & 30.41 & $1.76, \mathrm{~m}$ & 68 & 74.22 & $4.37, \mathrm{dd}, 7.6,2.9$ \\
\hline 27 & 74.63 & $3.54, \mathrm{~m}$ & 69 & 129.15 & $5.63, \mathrm{dd}, 16.5,8.0$ \\
\hline 28 & 72.59 & $3.71, \mathrm{~m}$ & 70 & 134.97 & $5.80, \mathrm{~m}$ \\
\hline 29 & 36.76 & $1.70, \mathrm{~m} ; 1.38, \mathrm{~m}$ & 71 & 33.59 & $2.19, \mathrm{~m}$ \\
\hline 30 & 33.59 & $1.97, \mathrm{~m}$ & 72 & 33.65 & $2.21, \mathrm{~m}$ \\
\hline 31 & 79.41 & $3.12, \mathrm{dd}, 7.6,2.8$ & 73 & 135.94 & $5.78, \mathrm{~m}$ \\
\hline 32 & 70.50 & $3.85, \mathrm{~m}$ & 74 & 131.97 & $6.10, \mathrm{dd}, 15.2,10.4$ \\
\hline 33 & 46.06 & $2.29, \mathrm{~m}$ & 75 & 134.75 & $6.21, \mathrm{dd}, 15.7,10.2$ \\
\hline 34 & 136.85 & null & 76 & 132.68 & $6.13, \mathrm{dd}, 15.7,10.2$ \\
\hline 35 & 129.54 & 5.72, br s & 77 & 138.61 & $6.35, \mathrm{ddd}, 16.9,10.2,10.2$ \\
\hline 36 & 144.65 & null & 78 & 116.68 & $5.15, \mathrm{dd}, 17.0,1.0 ; 5.01, \mathrm{dd}, 10.2,1.0$ \\
\hline 37 & 47.72 & $2.27, \mathrm{~m} ; 2.21, \mathrm{~m}$ & 79 & 17.25 & $0.97, d, 6.8$ \\
\hline 38 & 68.68 & $3.80, \mathrm{~m}$ & 80 & 18.51 & 1.84, br s \\
\hline 39 & 42.50 & $1.63, \mathrm{~m} ; 1.27 \mathrm{~m}$ & 81 & 115.77 & 5.05, br s; 4.85, br s \\
\hline 40 & 31.15 & $2.12, \mathrm{~m}$ & 82 & 13.91 & $0.90, d, 7.4$ \\
\hline 41 & 77.13 & $3.33, \mathrm{~m}$ & 83 & 17.39 & 1.74, br s \\
\hline 42 & 72.68 & $3.64, \mathrm{~m}$ & 84 & 113.21 & 5.07 , br s; 4.98 br s \\
\hline
\end{tabular}


Table 2. Percentage of growth inhibition of raw A. carterae extracts on cancer cells, bacteria and fungi.

\begin{tabular}{|c|c|c|c|c|c|}
\hline \multicolumn{6}{|c|}{ Anticancer screening ${ }^{a}$} \\
\hline Cancer cell line & A549 & A2058 & HepG2 & MCF7 & MiaPaca-2 \\
\hline$\%$ Growth Inhibition & 100 & 100 & 100 & 100 & 100 \\
\hline \multicolumn{6}{|c|}{ Antibacterial screening $b$} \\
\hline Bacteria & E. coli & K. pneumoniae & MRSA & MSSA & M. tuberculosis \\
\hline \% Growth Inhibition & 37 & 19 & 95 & 88 & 83 \\
\hline \multicolumn{6}{|c|}{ Antifungal screening $b$} \\
\hline Fungus & A. fumigatus & & & & \\
\hline \% Growth Inhibition & 100 & & & & \\
\hline
\end{tabular}

The crude methanol extract from A. carterae seemed to possess unspecific bioactivity and a clear toxicity profile, considering all the results from the cells and microorganisms tested. This was not surprising, since marine dinoflagellates belonging to the genus Amphidinium are well-known producers of different toxins [38], such as the amphidinolides [18].

Early HPLC-UV-MS analysis on the crude extracts revealed the presence of three possible amphidinols that were singled out because of their characteristic UV pattern (showing maxima of absorbance at 260, 270 and $280 \mathrm{~nm}$ due to a conjugated triene substructure), retention time and its $\mathrm{m} / \mathrm{z}$ values, which were close to some of the already known amphidinols [17,21]. The presence of these compounds may explain the antifungal and anticancer activities observed within the crude extract.

A $10 \mathrm{mg}$ aliquot from the crude extract was fractionated by semipreparative HPLC-DAD as reported in the methods section. Seven fractions (F1 to F7) were collected, dried, dissolved in 100\% DMSO and tested against $A$. fumigatus and C. albicans (Figure 1).

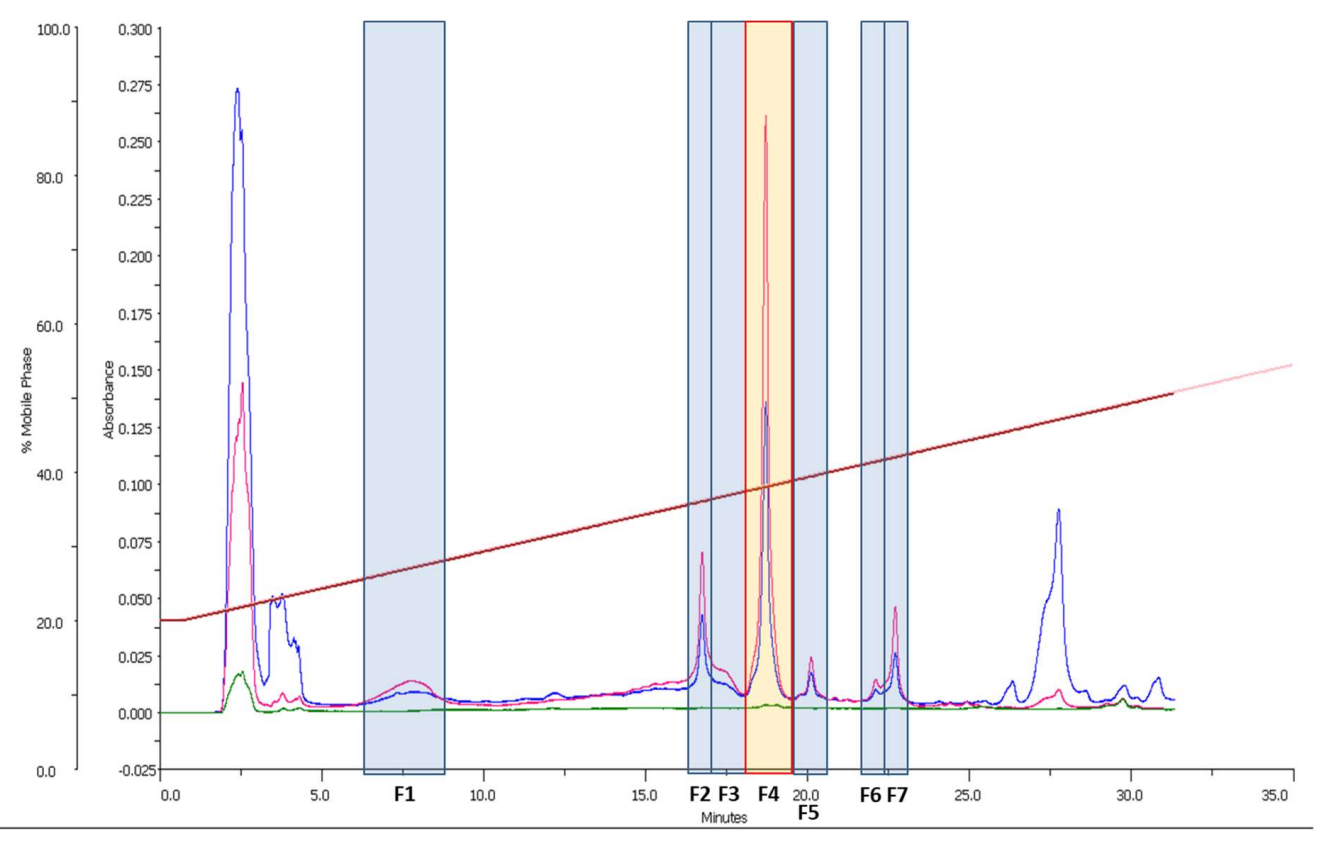

Figure 1. Fractions from the $A$. carterae extract aliquot. The fraction marked in yellow (F4) was active against $A$. fumigatus and C. albicans. Wavelengths selected were $210 \mathrm{~nm}$ (in blue), $260 \mathrm{~nm}$ (in pink) and $310 \mathrm{~nm}$ (in green). High $260 \mathrm{~nm}$ absorbance indicates the presence of the triene substructure in the amphidinols. 
HPLC-UV-MS analysis of the fractions and dereplication of the molecular formulae obtained led to the identification of F1 and F4 as amphidinol 19 (AM19, exact mass 1438.7894) and amphidinol 18 (AM18, exact mass 1358.8326), respectively (Figure 1). These two compounds were already discovered and tested by Nuzzo et al. [17]. In particular, AM18 displayed antifungal activity against $C$. albicans at $9 \mu \mathrm{g} / \mathrm{mL}$, but AM19 was not active. F2 was identified as an unknown compound related to amphidinols with a relatively high experimental accurate mass of 1644.9437. The largest amphidinols described so far were amphidinol 20 (AM20) and amphidinol 21 (AM21) [21], and their masses did not match with the mass obtained for the compound in F2. Fractions F3, F5, F6 and F7 corresponded to other amphidinol-related minor compounds.

The full A. carterae crude extract ( $5.7 \mathrm{~g}$ ) was then fractionated through reverse phase $\mathrm{C} 18$ flash chromatography. The compound detected in F2 (1.4 mg, accurate mass 1644.9437), now named amphidinol 22, was isolated together with AM18 from the flash fractions 19 and 20 by semipreparative reversed-phase HPLC.

\subsection{Structure Identification}

Amphidinol 22 was isolated as a pale yellow, amorphous solid. The data obtained from HPLC-UV-MS analysis confirmed UV absorption maxima at 260, 270 and $280 \mathrm{~nm}$, corresponding to the presence of a conjugated triene in the structure, typical among the amphidinols. The molecular formula of amphidinol 22 was deduced from the observed ammonium adduct $\left[\mathrm{M}+\mathrm{NH}_{4}\right]^{+}(\mathrm{m} / \mathrm{z}$ 1662.9705, calculated $m / z$ 1662.9717), indicative of a molecular formula $\mathrm{C}_{84} \mathrm{H}_{140} \mathrm{O}_{31}$ (degrees of unsaturation = 15).

Its ${ }^{13} \mathrm{C}$ NMR spectrum revealed the presence of 79 different carbon signals (anticipating the overlapping of some signals) of which 20 signals corresponded to $s p^{2}$ carbons, covering 10 out of the 15 unsaturations predicted by the molecular formula and suggesting the presence of five cycles. A total of 33 carbon signals corresponded to oxygenated carbons in a region between $\delta 55.11$ and $\delta 82.36 \mathrm{ppm}$. Two of them presented a particularly shielded chemical shift ( $\delta_{C}$ of 55.11 and 62.35 ), typical in epoxide groups. The ${ }^{1} \mathrm{H}$ NMR spectrum showed a high degree of signal overlap, especially in the region of the oxygenated protons ( $\delta_{\mathrm{H}}$ from 3 to $4 \mathrm{ppm}$ ), hence the multiplicity of only a few signals in the outermost regions was easily determined. The previous information together with the 2D-NMR hetero/homo-nuclear experiments performed (HSQC, COSY, HMBC and NOESY), allowed the identification of the planar structure of amphidinol 22 (Figure 2) by linking spin systems and giving information to overcome problems related to overlapped signals.

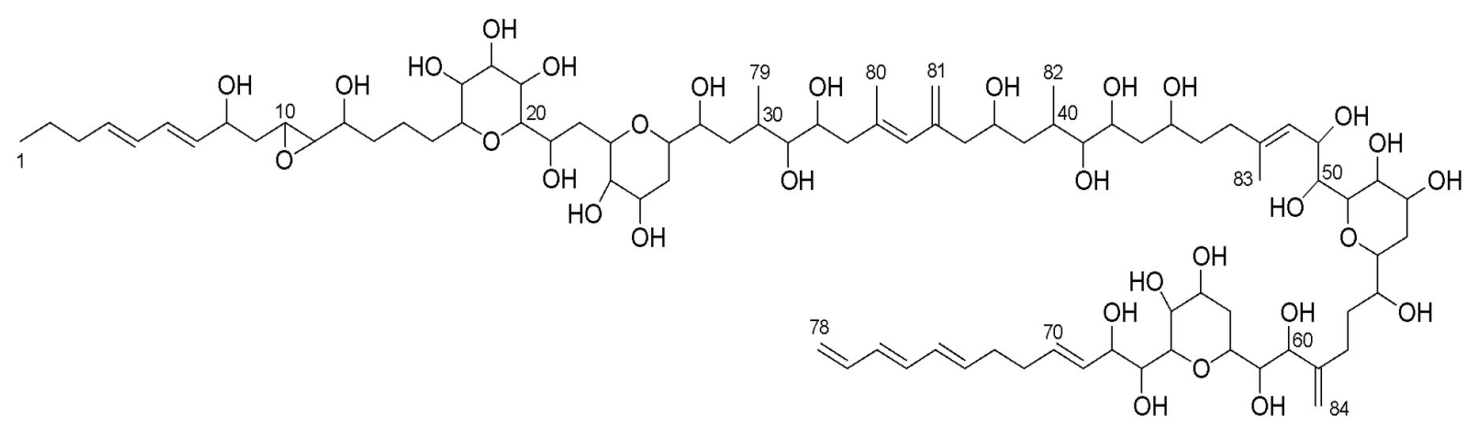

Figure 2. Planar structure of amphidinol 22.

The HSQC spectrum revealed that the carbon signals at $\delta_{\mathrm{C}} 30.41\left(2 \mathrm{CH}_{2}\right)$ and $33.59(\mathrm{CH}$ and $\left.\mathrm{CH}_{2}\right)$, and $\delta 36.68\left(2 \mathrm{CH}_{2}\right), 74.63(2 \mathrm{CH})$ and $76.77(2 \mathrm{CH})$ each accounted for two carbons, confirming the presence of 84 carbons in the molecule, and also confirmed that $\delta 136.85, \delta 139.30, \delta 144.65$ and $\delta 151.35$ were signals corresponding to four $s p^{2}$ quaternary carbons. A comparative approach with the data available from AM18 and AM19 [17], together with the COSY data from our molecule and the HMBC correlations when the overlapping in the ${ }^{1} \mathrm{H}$ NMR signals was found (Table S9, Supplementary information), were used to establish the presence of four spin systems in the proposed 
structure (Figure 3): A (from H1 to H33), B (from H37 to H46), C (from H48 to H58) and, finally, D (from H60 to H78). Almost all COSY signals within the spin systems were well visible and, in addition, long distance COSY correlations were observed between H35, H80 and H81, confirming their proximity. The similarities of the chemical shifts with AM18 and the HMBC correlations confirmed the basic structure.

Key HMBC correlations (Figure 3) allowed to link all the spin systems present in the structure. The cross-peaks at $\delta 2.29 / 18.51$ (H33/C 80$), \delta 2.29 / 129.54$ (H33/C35), $\delta 2.29 / 136.85$ (H33/C34), $\delta$ $1.84 / 46.06(\mathrm{H} 80 / \mathrm{C} 33), \delta 1.84 / 136.85$ (H80/C34) and $\delta 1.84 / 129.54(\mathrm{H} 80 / \mathrm{C} 35)$, together with the signals at $\delta 2.27-2.21 / 115.77$ (H37/C 81$), \delta 2.27-2.21 / 144.65$ (H37/C36), $\delta 2.27-2.21 / 129.54$ (H37/C35), $\delta$ 5.05-4.85/129.54 (H81/C35), $85.05-4.85 / 144.65$ (H81/C36) and $85.05-4.85 / 47.72$ (H81/C37), allowed to link the spin systems A and B. The HMBC signals H80/C35 and H81/C35, and previously reported COSY signals confirmed the position of $\mathrm{CH}-35$.

Spin system $B$ and $C$ were linked by the $\mathrm{CH}_{2}-46$ cross-peaks in the HMBC at $\delta 2.20-2.11 / 126.24$ (H46/C48), $\delta 2.20-2.11 / 139.30$ (H46/C47) and $\delta 2.20-2.11 / 17.39$ (H46/C83), in addition to those of the CH-48 signals at $\delta 5.48 / 17.39$ (H48/C83) and $\delta 5.48 / 36.68$ (H48/C46). This link was confirmed with the HMBC correlations of the $\mathrm{CH}_{3}-83$ signals at $\delta 1.74 / 36.68$ (H83/C46), $\delta 1.74 / 139.30$ (H83/C47) and $\delta$ 1.74/126.24 (H83/C48).

Spin systems $\mathrm{C}$ and D were linked by the HMBC signals of $\mathrm{CH}_{2}-58$ at $\delta 2.41-2.09 / 151.35$ (H58/C59), $\delta 2.41-2.09 / 76.77$ (H58/C60) and $\delta$ 2.41-2.09/113.21 (H58/C84), together with the CH-60 HMBC signals at $\delta 4.18 / 151.35$ (H60/C59), $\delta 4.18 / 27.89$ (H60/C58) and $\delta 4.18 / 113.21$ (H60/C84). This link was confirmed with the cross-peaks displayed by $\mathrm{CH}_{2}-84$ signals at $\delta 5.07-4.98 / 27.89$ (H84/C58), $\delta 5.07-4.98 / 151.35$ (H84/C59) and 85.07-4.98/76.77 (H84/C60).

Finally, HMBC correlations also allowed to localize four ether bridges along the structure by the through-oxygen cross-peaks at $\delta 3.14 / 81.54$ (H20/C16), $\delta 4.22 / 74.63$ (H23/C27), $\delta 3.48 / 79.21$ (H55/C51) and $83.74 / 70.41(\mathrm{H} 66 / \mathrm{C} 62)$.

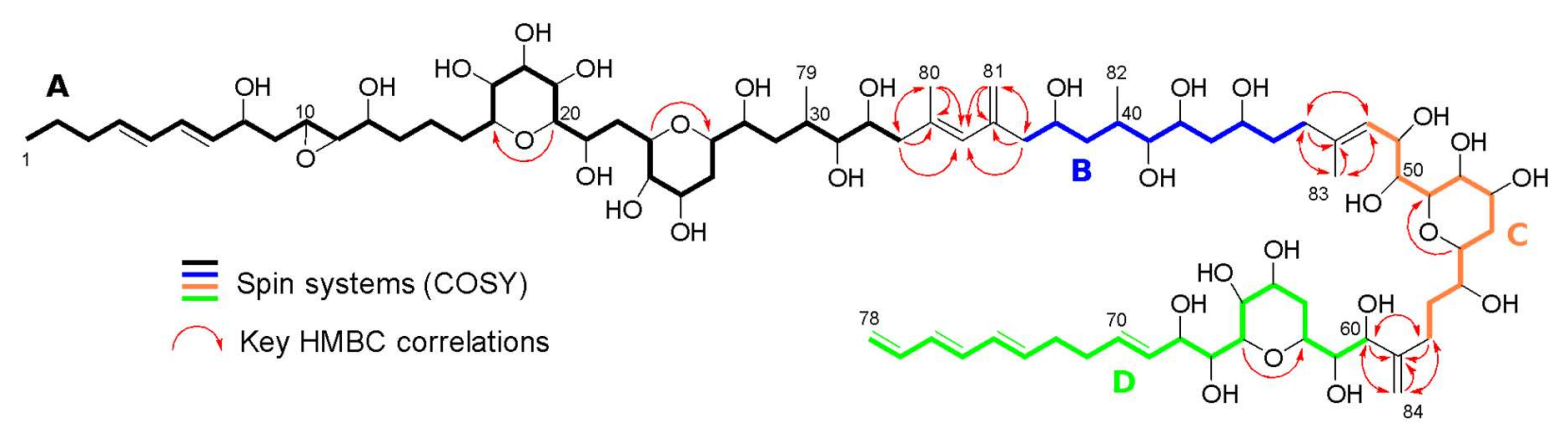

Figure 3. Spin systems and key HMBC correlations of amphidinol 22. The spin systems appear in different colors as follows: A (black), B (blue), C (orange) and D (green).

The magnitude of the coupling constants of the signals belonging to the $\Delta^{4}, \Delta^{6}, \Delta^{69}, \Delta^{73}$ and $\Delta^{75}$ double bonds, higher than $15 \mathrm{~Hz}$ in all cases (see Table 1), allowed us to establish their $E$ configuration. NOESY signals observed for the pairs $\mathrm{H} 33 / \mathrm{H} 35$ and $\mathrm{H} 46 / \mathrm{H} 48$ also confirmed the $E$ configuration of the $\Delta^{34}$ and $\Delta^{47}$ double bonds. Although determination of the full the three dimensional structure of the molecule is out of the scope of this report, the configuration of the common substructure in amphidinol 22 might be the same as the one already reported for AM18, AM19, AM20 and AM21 (Figure 4), due to similar chemical shifts and coupling constants around this region $[17,21]$. 


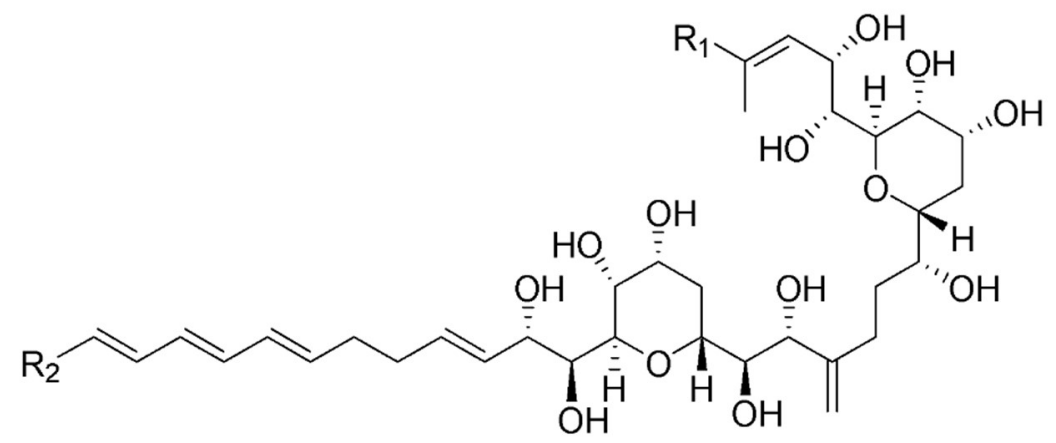

Figure 4. Reported stereochemistry of already known amphidinols in the common substructure with amphidinol 22.

\subsection{Amphidinol 22 Bioactivities}

In this section, the anticancer and antimicrobial bioactivities of amphidinol 22 are reported. The compound was evaluated against five different cancer cell lines (i.e., A549, A2058, HepG2, MCF7 and MiaPaca2) and five different microorganisms (i.e., A. fumigatus, C. albicans, MRSA, MSSA and M. tuberculosis).

\subsubsection{Anticancer Activity}

MTT assays were performed on human lung carcinoma A549 ATCC ${ }^{\circledR}$ CCL-185 ${ }^{\mathrm{TM}}$, human skin melanoma A2058 ATCC ${ }^{\circledR}$ CRL-11147" ${ }^{\mathrm{TM}}$, hepatocyte carcinoma HepG2 ATCC ${ }^{\circledR}$ HB-8065 ${ }^{\mathrm{TM}}$, breast adenocarcinoma MCF7 ATCC ${ }^{\circledR}$ HTB-22 ${ }^{\mathrm{TM}}$ and pancreas carcinoma MiaPaca-2 ATCC ${ }^{\circledR}$ CRL-1420 ${ }^{\mathrm{TM}}$ cell lines to assay the potential anticancer activity of amphidinol 22. The compound displayed general cytotoxicity on all the cell lines tested (Figure 5). Its IC 50 values on A549, A2058, HepG2, MCF7 and MiaPaca-2 cell lines were $8 \mu \mathrm{M}, 16.4 \mu \mathrm{M}, 6.8 \mu \mathrm{M}, 16.8 \mu \mathrm{M}$ and $8.6 \mu \mathrm{M}$, respectively.

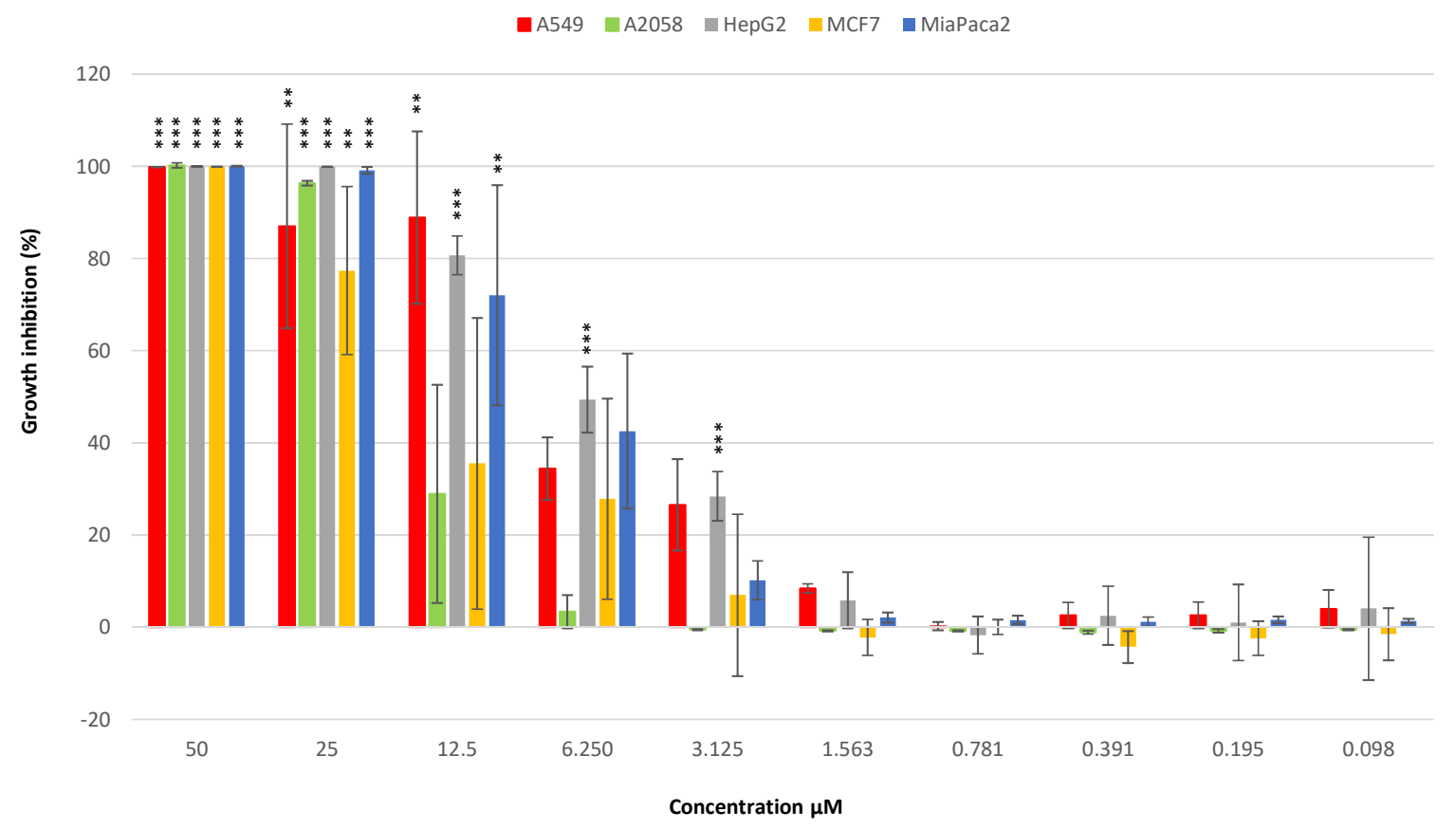

Figure 5. Percentage cell viability inhibition of A549 (lung), A2058 (skin), HepG2 (liver), MCF7 (breast) and Miapaca-2 (pancreas) cancer cell lines after incubation for $72 \mathrm{~h}$ with 0.098, 0.195, 0.391, 0.781, 1.563, $3.125,6.250,12.5,25,50 \mu \mathrm{M}$ of amphidinol 22 (** for $p<0.01$ and ${ }^{* * *}$ for $p<0.001$, Student's $t$-test). Experiments were performed in triplicate. 
The anticancer properties of another member of the amphidinol family, amphidinol 2 (AM2, first isolated by Paul et al. [39]) were already reported by Espiritu et al. [29]. The anticancer activity was evaluated against HCT-116 (colon carcinoma), HT29 (colon adenocarcinoma) and MCF-7 cancer cell lines and IC50 values were in the range of 1 to $7 \mu \mathrm{M}$. An up-regulation (100-folds) of the early apoptotic markers cfos/cjun, in all the cancer cells, was observed after treatment with AM2.

Other compounds from Amphidinium spp. have also been reported earlier to display anticancer activity, such as the cytotoxic macrolides amphinolide $\mathrm{G}$ and amphinolide $\mathrm{H}$. These two compounds, especially amphidinolide $\mathrm{H}$, exhibited extremely strong cytotoxic activities against L1210 murine leukemia cells with $\mathrm{IC}_{50}$ values of 0.0054 and $0.00048 \mu \mathrm{g} / \mathrm{mL}$ and $\mathrm{KB}$ human epidermoid carcinoma cells IC50 values of 0.0059 and $0.00052 \mu \mathrm{g} / \mathrm{mL}$, respectively [40]. The mechanism of action was related to covalent binding on the actin Tyr200 subdomain [41].

\subsubsection{Antifungal Activity}

The antifungal activity was assessed by testing amphidinol 22 against C. albicans and A. fumigatus strains. The compound showed antifungal activity against both fungi, with a MIC value of $64 \mu \mathrm{g} / \mathrm{mL}$ in both cases. Since isolation and identification of the first member of amphidinols' family [27], almost all the amphidinols discovered to date have presented antifungal activity. Echigoya and co-workers showed a strong antifungal activity on Aspergillus niger for AM2, AM4 and AM9 (44.3, 58.2 and $32.9 \mu \mathrm{g}$ extract per disk, respectively) and a lower activity for AM10, AM11, AM12, AM13 (>100-256.6 $\mu \mathrm{g}$ extract per disk) [20]. In addition, Nuzzo et al. showed that amphidinol 18 (AM18) was active against the fungus $C$. albicans $(9 \mu \mathrm{g} / \mathrm{mL})$ [17]. In 2017, Satake et al. identified the largest amphidinol homologues (AM20 and AM21) [21], but their antifungal activities were low compared to the activities reported for AM6 and AM2 [22].

\subsubsection{Antibacterial Activity}

The anti-bacterial activity of amphidinol 22 was evaluated as well. Assays were performed on Gram-positive bacteria (S. aureus MRSA and S. aureus MSSA) and M. tuberculosis, and no growth inhibition was observed. Hence, the compound did not display any antibacterial effect.

\section{Conclusions}

Bioassay-guided fractionation allowed the isolation and identification of a new compound belonging to the amphidinol family, which we designated as amphidinol 22, from the dinoflagellate A. carterae. It presents different structural features when compared to the other related compounds, including an extra pyran ring and an oxirane group. Bioactivity testing performed for this compound showed that it has cytotoxic and antifungal properties. Amphidinol 22 cytotoxic activity was in range with the already reported activities by Espiritu et al. for AM2 (1 to $7 \mu \mathrm{M})$ [29]. On the other hand, AM18 and amphidinol A are the only amphidinols that have been tested for antifungal activity using the MIC assay, and therefore the only studies we can use as a reference. However, the antifungal activity of amphidinol 22 on C. albicans (MIC $64 \mu \mathrm{g} / \mathrm{mL}$ ) is less potent compared to these molecules (MIC $9 \mu \mathrm{g} / \mathrm{mL}$ for AM18 and $19 \mu \mathrm{g} / \mathrm{mL}$ for amphidinol A) [17,28].

In order to better characterize its mechanism of action, higher amounts of the compound are necessary, as well as further research on biomedical, toxicological, chemical, pharmacological and therapeutic potential. Microalgae have been shown to produce compounds with anticancer and anti-microbial activities and to be cultivable for mass cultivation and massive compound production in photobioreactors $[1,12,42-47]$. Until now, very few pure compounds have been isolated and characterized from microalgae, and they are a still poorly explored resource for drug discovery. This study confirm that they are an excellent reservoir of new marine natural products with applications for various human pathologies. 
Supplementary Materials: The following are available online at http://www.mdpi.com/1660-3397/17/7/385/s1, Figure S1: 1H NMR spectrum of amphidinol $22(500 \mathrm{MHz})$ in CD3OD, Figure S2: 13C NMR spectrum of amphidinol $22(125 \mathrm{MHz})$ in CD3OD, Figure S3: HSQC spectrum of amphidinol 22, Figure S4: COSY spectrum of amphidinol 22, Figure S5: HMBC spectrum of amphidinol 22, Figure S6: NOESY spectrum of amphidinol 22, Figure S7: LC-UV trace and UV and HRESIMS spectra of amphidinol 22, Figure S8: Expansions of the HRESIMS spectrum of amphidinol 22, and Table S9: Tabulated 2D NMR data of amphidinol 22.

Author Contributions: Conceptualization, K.A.M. and C.L.; data curation, K.A.M., C.L., J.M., C.D., B.C. and M.d.1.C.; methodology, K.A.M., C.L., D.D., G.R., T.G., J.M, C.D., B.C. and M.d.l.C; resources, K.A.M., C.L. and F.R.; supervision, A.I. and F.R.; writing-original draft, K.A.M. and C.L.; and writing-review and editing, K.A.M., C.L., G.R., M.J., A.I. and F.R.

Funding: The research leading to these results has received funding from Marie Skłodowska-Curie Innovative Training Networks PhD (Project Marpipe MSCA-ITN-ETN Proposal number: 721421) and European Union 7th Framework Program PHARMASEA (312184).

Acknowledgments: We thank Massimo Perna and Mariano Amoroso for their technical support and Flora Palumbo for graphics (Stazione Zoologica Anton Dohrn). We thank Jose Ruben Tormo, Paqui Muñoz, Catalina Moreno and Pilar Sanchez for their technical support (Fundación MEDINA).

Conflicts of Interest: The authors declare no conflict of interest.

\section{References}

1. Kobayashi, J.; Kubota, T. Bioactive Metabolites from Marine Dinoflagellates. In Comprehensive Natural Products II: Chemistry and Biology; Mander, L., Lui, H.-W., Eds.; Elsevier Science: Oxford, UK, 2010. [CrossRef]

2. Kathiresan, K.; Nabeel, M.A.; Manivannan, S. Bioprospecting of marine organisms for novel bioactive compounds. Sci. Trans. Environ. Technovation 2017, 1, 107-120. [CrossRef]

3. Guedes, A.C.; Gião, M.S.; Seabra, R.; Ferreira, A.C.S.; Tamagnini, P.; Moradas-Ferreira, P.; Malcata, F.X. Evaluation of the antioxidant activity of cell extracts from microalgae. Mar. Drugs 2013, 11, 1256-1270. [CrossRef] [PubMed]

4. Chaudhuri, D.; Ghate, N.B.; Deb, S.; Panja, S.; Sarkar, R.; Rout, J.; Mandal, N. Assessment of the phytochemical constituents and antioxidant activity of a bloom forming microalgae Euglena tuba. Biol. Res. 2014, 47, 24. [CrossRef] [PubMed]

5. Samarakoon, K.W.; Ko, J.Y.; Shah, M.M.R.; Lee, J.H.; Kang, M.C.; O-Nam, K.; Lee, J.B.; Jeon, Y.J. In vitro studies of anti-inflammatory and anticancer activities of organic solvent extracts from cultured marine microalgae. Algae 2013, 28, 111-119. [CrossRef]

6. Pasquet, V.; Morisset, P.; Ihammouine, S.; Chepied, A.; Aumailley, L.; Berard, J.B.; Serive, B.; Kaas, R.; Lanneluc, I.; Thiery, V.; et al. Antiproliferative activity of violaxanthin isolated from bioguided fractionation of Dunaliella tertiolecta extracts. Mar. Drugs 2011, 9, 819-831. [CrossRef] [PubMed]

7. Kobayashi, J.; Kubota, T. Bioactive Macrolides and Polyketides from Marine Dinoflagellates of the Genus Amphidinium. J. Nat. Prod. 2007, 70, 451-460. [CrossRef] [PubMed]

8. Baudelet, P.H.; Gagez, A.L.; Bérard, J.B.; Juin, C.; Bridiau, N.; Kaas, R.; Thiéry, V.; Cadoret, J.P.; Picot, L. Antiproliferative activity of Cyanophora paradoxa pigments in melanoma, breast and lung cancer cells. Mar. Drugs 2013, 11, 4390-4406. [CrossRef] [PubMed]

9. Castrec, J.; Soudant, P.; Payton, L.; Tran, D.; Miner, P.; Lambert, C.; Le Goïc, N.; Huvet, A.; Quillien, V.; Boullot, F.; et al. Bioactive extracellular compounds produced by the dinoflagellate Alexandrium minutum are highly detrimental for oysters. Aquat. Toxicol. 2018, 199, 188-198. [CrossRef] [PubMed]

10. Sanmukh, S. Bioactive Compounds Derived from Microalgae Showing Antimicrobial Activities. J. Aquac. Res. Dev. 2014, 5, 3. [CrossRef]

11. Mimouni, V.; Ulmann, L.; Pasquet, V.; Mathieu, M.; Picot, L.; Bougaran, G.; Cadoret, J.; Morant-Manceau, A.; Schoefs, B. The Potential of Microalgae for the Production of Bioactive Molecules of Pharmaceutical Interest. Curr. Pharm. Biotechnol. 2012, 13, 2733-2750. [CrossRef] [PubMed]

12. Martínez Andrade, K.A.; Lauritano, C.; Romano, G.; Ianora, A. Marine microalgae with anti-cancer properties. Mar. Drugs 2018, 16, 165. [CrossRef] [PubMed]

13. Lauritano, C.; Ferrante, M.I.; Rogato, A. Marine Natural Products from Microalgae: An Omics Overview. Mar. Drugs 2019, 17, 269. [CrossRef] [PubMed]

14. Tomas, C.R.; Hasle, G.R.; Syvertsen, E.E.; Steidinger, K.A.; Tangen, K. Identifying Marine Diatoms and Dinoflagellates; Elsevier: Amsterdam, The Netherlands, 1996. 
15. Pagliara, P.; Caroppo, C. Toxicity assessment of Amphidinium carterae, Coolia cfr. monotis and Ostreopsis cfr. ovata (Dinophyta) isolated from the northern Ionian Sea (Mediterranean Sea). Toxicon 2012, 60, 1203-1214. [CrossRef] [PubMed]

16. Shah, M.M.R.; Samarakoon, K.W.; Ko, J.; Lakmal, H.C.; Lee, J.; An, S.; Jeon, Y. Potentiality of benthic dinoflagellate cultures and screening of their bioactivities in Jeju Island, Korea. Afr. J. Biotechnol. 2014, 13, 792-805. [CrossRef]

17. Nuzzo, G.; Cutignano, A.; Sardo, A.; Fontana, A. Antifungal amphidinol 18 and its 7-sulfate derivative from the marine dinoflagellate Amphidinium carterae. J. Nat. Prod. 2014, 77, 1524-1527. [CrossRef] [PubMed]

18. Kobayashi, J. Amphidinolides and its related macrolides from marine dinoflagellates. J. Antibiot. 2008, 61, 271-284. [CrossRef] [PubMed]

19. Kumagai, K.; Minamida, M.; Akakabe, M.; Tsuda, M.; Konishi, Y.; Tominaga, A.; Tsuda, M.; Fukushi, E.; Kawabata, J. Amphirionin-2, a novel linear polyketide with potent cytotoxic activity from a marine dinoflagellate Amphidinium species. Biorg. Med. Chem. Lett. 2015, 25, 635-638. [CrossRef] [PubMed]

20. Echigoya, R.; Rhodes, L.; Oshima, Y.; Satake, M. The structures of five new antifungal and hemolytic amphidinol analogs from Amphidinium carterae collected in New Zealand. Harmful Algae 2005, 4, 383-389. [CrossRef]

21. Satake, M.; Cornelio, K.; Hanashima, S.; Malabed, R.; Murata, M.; Matsumori, N.; Zhang, H.; Hayashi, F.; Mori, S.; Kim, J.S.; et al. Structures of the Largest Amphidinol Homologues from the Dinoflagellate Amphidinium carterae and Structure-Activity Relationships. J. Nat. Prod. 2017, 80, 2883-2888. [CrossRef]

22. Morsy, N.; Konoki, K.; Houdai, T.; Matsumori, N.; Oishi, T.; Murata, M.; Aimoto, S. Roles of integral protein in membrane permeabilization by amphidinols. Biochim. Biophys. Acta Biomembr. 2008, 1778, 1453-1459. [CrossRef]

23. Washida, K.; Koyama, T.; Yamada, K.; Kita, M.; Uemura, D. Karatungiols A and B, two novel antimicrobial polyol compounds, from the symbiotic marine dinoflagellate Amphidinium sp. Tetrahedron Lett. 2006, 47, 2521-2525. [CrossRef]

24. Kellmann, R.; Stüken, A.; Orr, R.J.S.; Svendsen, H.M.; Jakobsen, K.S. Biosynthesis and molecular genetics of polyketides in marine dinoflagellates. Mar. Drugs 2010, 8, 1011-1048. [CrossRef] [PubMed]

25. Kohli, G.S.; John, U.; Van Dolah, F.M.; Murray, S.A. Evolutionary distinctiveness of fatty acid and polyketide synthesis in eukaryotes. ISME J. 2016, 10, 1877-1890. [CrossRef] [PubMed]

26. Lauritano, C.; De Luca, D.; Ferrarini, A.; Avanzato, C.; Minio, A.; Esposito, F.; Ianora, A. De novo transcriptome of the cosmopolitan dinoflagellate Amphidinium carterae to identify enzymes with biotechnological potential. Sci. Rep. 2017, 7, 1-12. [CrossRef] [PubMed]

27. Satake, M.; Murata, M.; Yasumoto, T.; Fujita, T.; Naoki, H. Amphidinol, a Polyhydroxypolyene Antifungal Agent with an Unprecedented Structure, from a Marine Dinoflagellate, Amphidinium klebsii. J. Am. Chem. Soc. 1991, 113, 9859-9861. [CrossRef]

28. Cutignano, A.; Nuzzo, G.; Sardo, A.; Fontana, A. The Missing piece in biosynthesis of amphidinols: First evidence of glycolate as a starter unit in New Polyketides from Amphidinium carterae. Mar. Drugs 2017, 15, 157. [CrossRef] [PubMed]

29. Espiritu, R.A.; Tan, M.S.; Oyong, G.G. Evaluation of the anti-cancer potential of amphidinol 2, a polyketide metabolite from the marine dinoflagellate Amphidinium klebsii. Jordan, J. Biol. Sci. 2017, 10, 297-302.

30. Keller, M.D.; Selvin, R.C.; Claus, W.; Guillard, R.R.L. Media for the culture of oceanic ultraphytoplankton. J. Phycol. 1987, 23, 633-638. [CrossRef]

31. Escalera, L.; Reguera, B.; Moita, T.; Pazos, Y.; Cerejo, M.; Cabanas, J.M.; Ruiz-Villarreal, M. Bloom dynamics of Dinophysis acuta in an upwelling system: In situ growth versus transport. Harmful Algae 2010, 9, 312-322. [CrossRef]

32. Audoin, C.; Bonhomme, D.; Ivanisevic, J.; De La Cruz, M.; Cautain, B.; Monteiro, M.C.; Reyes, F.; Rios, L.; Perez, T.; Thomas, O.P. Balibalosides, an original family of glucosylated sesterterpenes produced by the Mediterranean sponge Oscarella balibaloi. Mar. Drugs 2013, 11, 1477-1489. [CrossRef]

33. Palomino, J.-C.; Martin, A.; Camacho, M.; Guerra, H.; Swings, J.; Portaels, F. Resazurin Microtiter Assay Plate: Simple and Inexpensive Method for Detection of Drug Resistance in Mycobacterium tuberculosis. Antimicrob. Agents Chemother. 2002, 46, 2720-2722. [CrossRef] [PubMed] 
34. Martín, J.; Crespo, G.; González-Menéndez, V.; Pérez-Moreno, G.; Sánchez-Carrasco, P.; Pérez-Victoria, I.; Ruiz-Pérez, L.M.; González-Pacanowska, D.; Vicente, F.; Genilloud, O.; et al. MDN-0104, an antiplasmodial betaine lipid from Heterospora chenopodii. J. Nat. Prod. 2014, 77, 2118-2123. [CrossRef] [PubMed]

35. Perez-Victoria, I.; Martin, J.; Reyes, F. Combined LC/UV/MS and NMR Strategies for the Dereplication of Marine Natural Products. Planta Med. 2016, 82, 857-871. [CrossRef] [PubMed]

36. Taylor \& Francis Group Dictionary of Marine Natural Products. Available online: http://dmnp.chemnetbase. com/faces/chemical/ChemicalSearch.xhtml (accessed on 22 May 2019).

37. National Center for Biotechnology Information PubChem. Available online: https://pubchem.ncbi.nlm.nih. gov/ (accessed on 22 May 2019).

38. Karafas, S.; Teng, S.T.; Leaw, C.P.; Alves-de-Souza, C. An evaluation of the genus Amphidinium (Dinophyceae) combining evidence from morphology, phylogenetics, and toxin production, with the introduction of six novel species. Harmful Algae 2017, 68, 128-151. [CrossRef] [PubMed]

39. Paul, G.K.; Matsumori, N.; Murata, M.; Tachibana, K. Isolation and chemical structure of amphidinol 2, a potent hemolytic compound from marine dinoflagellate Amphidinium klebsii. Tetrahedron Lett. 1995, 36, 6279-6282. [CrossRef]

40. Kobayashi, J.; Hideyuki, S.; Masami, I.; Terufumi, Y.; Hiroshi, H.; Takuma, S. Amphidinolides G and H: New Potent Cytotoxic Macrolides from the Cultured Symbiotic Dinoflagellate Amphidinium sp. J. Org. Chem. 1991, 56, 5221-5224. [CrossRef]

41. Usui, T.; Kazami, S.; Dohmae, N.; Mashimo, Y.; Kondo, H.; Tsuda, M.; Terasaki, A.G.; Ohashi, K.; Kobayashi, J.; Osada, H. A potent cytotoxic macrolide, covalently binds on actin subdomain 4 and stabilizes actin filament. Chem. Biol. 2004, 11, 1269-1277. [CrossRef]

42. Lauritano, C.; Martín, J.; De La Cruz, M.; Reyes, F.; Romano, G.; Ianora, A. First identification of marine diatoms with anti-tuberculosis activity. Sci. Rep. 2018, 8, 1-10. [CrossRef]

43. Yaakob, Z.; Ali, E.; Zainal, A.; Mohamad, M.; Takriff, M.S. An overview: Biomolecules from microalgae for animal feed and aquaculture. J. Biol. Res. (Thessalon.) 2014, 21, 6. [CrossRef]

44. Assunção, J.; Guedes, A.; Malcata, F. Biotechnological and Pharmacological Applications of Biotoxins and Other Bioactive Molecules from Dinoflagellates. Mar. Drugs 2017, 15, 393. [CrossRef]

45. Lauritano, C.; Andersen, J.H.; Hansen, E.; Albrigtsen, M.; Escalera, L.; Esposito, F.; Helland, K.; Hanssen, K.Ø.; Romano, G.; Ianora, A. Bioactivity screening of microalgae for antioxidant, anti-inflammatory, anticancer, anti-diabetes and antibacterial activities. Front. Mar. Sci. 2016, 3, 68. [CrossRef]

46. Giordano, D.; Costantini, M.; Coppola, D.; Lauritano, C.; Núñez Pons, L.; Ruocco, N.; di Prisco, G.; Ianora, A.; Verde, C. Biotechnological applications of bioactive peptides from marine sources. Adv. Microb. Physiol. 2018, 73, 171-220. [CrossRef] [PubMed]

47. Romano, G.; Costantini, M.; Sansone, C.; Lauritano, C.; Ruocco, N.; Ianora, A. Marine microorganisms as a promising and sustainable source of bioactive molecules. Mar. Environ. Res. 2017, 128, 58-69. [CrossRef] [PubMed]

(C) 2019 by the authors. Licensee MDPI, Basel, Switzerland. This article is an open access article distributed under the terms and conditions of the Creative Commons Attribution (CC BY) license (http://creativecommons.org/licenses/by/4.0/). 